\title{
Effects of Season and Frequency of Burning on a Phryganic Rangeland in Greece
}

\author{
VASILIOS P. PAPANASTASIS
}

\begin{abstract}
Phryganic rangelands dominated by Sarcopoterium spinosum, a thorny and unpalatable dwarf shrub, are a common vegetation type over the eastern Mediterranean countries. In such a rangeland of northern Greece, the effect of early spring and fall burning, applied once, twice, and three times in a 3-year period, was studied. Season of burning did not have any significant effect on the dominant shrub. Frequency of burning, however, significantly reduced the plant yields but altered species composition only slightly and had no effect on soil organic matter and acidity. Burning has only temporary effects on phryganic rangelands due to the high regeneration capacity of the component species. If prescribed, fire can be used a a tool to suppress the shrub and increase the availability of herbage for the benefit of the grazing animals.
\end{abstract}

Plant communities dominated by Sarcopoterium spinosum (L.) Spach., a thorny and flammable dwarf shrub of less than $50 \mathrm{~cm}$ tall, are a common vegetation type in the eastern Mediterrannean countries (Litav and Orshan 1971). In Greece, such communities are known as "phrygana" and they are widespread in areas with long, dry, and hot summers and mild and rainy winters, normally found in the southern part of the country. They usualy grow on dry, rocky, and friable soils without active calcium (Debazac and Mavrommatis 1969).

Phrygana are more open communities than are mediterranean maquis or chaparral and they have an important herbaceous element. Physiognomically, they can compare with the coastal sage scrub, the vegetation type which lies below chaparral and extends to the South Coast Ranges of California (Munz and Keck 1968).

Phryganic communities are important grazing lands for livestock, mainly sheep, in the winter time. Sarcopoterium spinosum, however, is unpalatable to these animals, while its spines injure them. In places where it gets dense, free movement of sheep becomes impossible and considerable area of valuable grazing land is thus lost.

To control this troublesome species and to, consequently, increase the grazing capacity of the phryganic rangelands, shepherds have been using fire for a long time. However, the fires set by those people are uncontrolled and usually have more harmful than desirable effects (Papanastasis 1977).

If fire is to be used rationally in management of phryganic rangelands, a full knowledge of its ecological role in those ecosystems is needed. Furthermore, precise information is required on the effects of prescribed burning if it is going to be applied for improvement of these grazing areas.

The effects of fire on range communities have received considerable attention and some excellent reviews are

Author is range scientist, Forest Research Institute, Vassilika, Thessaloniki, Greece.

Manuscript received March 20, 1979. available (Biswell 1974; Daubenmire 1968; Naveh 1974; Wright 1974; Mueggler 1976). Nevertheless, information on fire ecology and management on the phryganic communities is scanty (Papanastasis 1977).

The objective of this paper was to study the effects of season and frequency of burning on the phryganic rangelands for a better understanding of the ecological role of fire as well as its use for rational management of those areas for the benefit of livestock and the wild animals.

\section{Study Area}

A phryganic rangeland located in the hills of the city of Thessaloniki, Northern Greece, was selected as a study site. The community had not been burned for more than 20 years and it was commonly grazed by sheep. The area had a south exposure and about $20 \%$ slope.

Besides Sarcopoterium spinosum, covering about $30 \%$ of the ground, herbaceous species were also a significant part of the vegetation cover (Fig. 1). Soil was a shallow sandy loam. Parent rock, made up of basic intrusives (peridotite, serpentine, gabbre, diabase) was often exposed at the surface. Annual rainfall of the area amounts to $500 \mathrm{~mm}$ and average annual temperature to $16^{\circ} \mathrm{C}$.

\section{Methods}

The experimental design consisted of two seasons and three frequencies of burning applied in a 3-year time period. Burning was conducted either in the spring or in the fall of 1974, 1975, and 1976. Within each season, plots were either burned once, i.e. only in

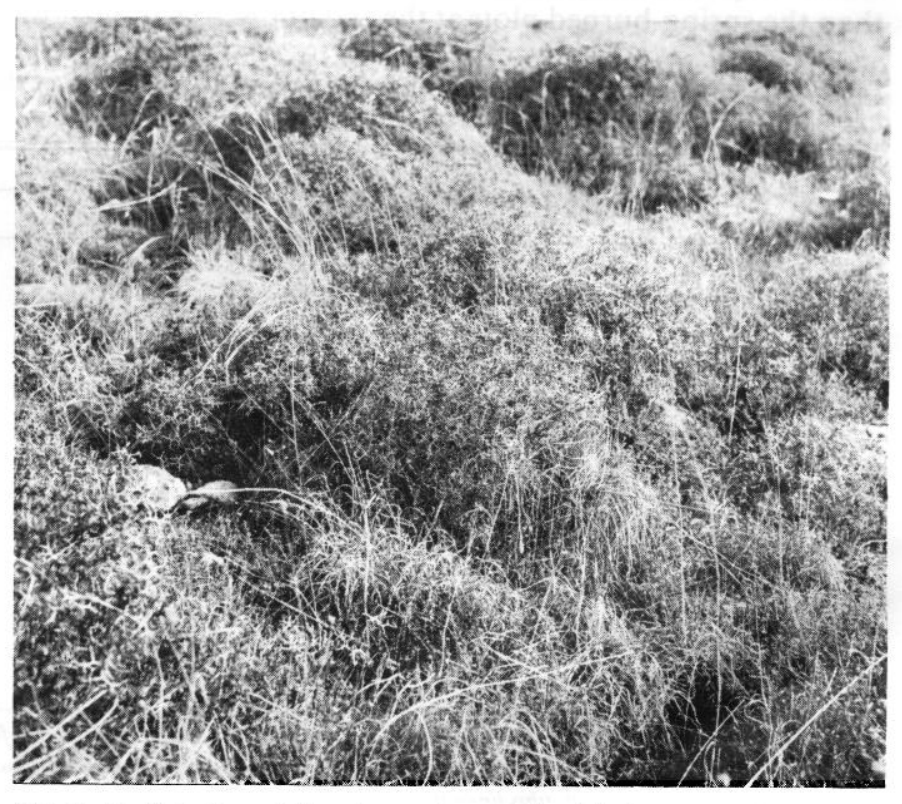

Fig. 1. Partial view of the phryganic rangeland before it was burned. 
1974, or for two consecutive years, i.e. in 1974 and 1975 , or every year, i.e. in 1974, 1975, and 1976. Hereafter frequencies will be referred to as once, twice, and thrice.

The six treatment combinations along with a control (no burning) were randomly established on an area 0.14 ha in size. Each plot was $200 \mathrm{~m}^{2}$. By erecting a barb wire fence, no livestock grazing was allowed during the course of the experiment.

Spring burning was done in early March when Sarcopoterium spinosum had started to flower. Fall burning, on the other hand, was done in late September, when most of its mature seeds had fallen off. To secure uniform burning of the vegetation a gasolinemotored flame thrower was used to set the fire. Approximate weather conditions during burning were $8^{\circ} \mathrm{C}$ and $15^{\circ} \mathrm{C}$ air temperature, $55 \%$ and $75 \%$ relative humidity, and $7 \mathrm{~km} / \mathrm{h}$ and 5 $\mathrm{km} / \mathrm{h}$ wind speed, respectively, for the spring and the fall seasons.

Measurements were taken one growing season after the last fall fire, in June 1977, which was considered the end of the 3-year burning period. Vegetative cover was measured with the loop method (Joint Committee 1962). Five transects of $10 \mathrm{~m}$ long were randomly taken in each plot and 20 readings with the $2 \mathrm{~cm}$ wide loop were made in each transect. Meanwhile, two square quadrats of $0.12 \mathrm{~m}^{2}$ were randomly placed under each transect and the plant material (live and dead) was clipped to the ground level. Plant biomass was also measured at the end of the two previous growing seasons (1975 and 1976) but only in the once-burned plots.

In the meantime, permanent quadrats of $0.25 \times 0.25 \mathrm{~m}^{2}$ were established after the first fall fire, one in each plot, and regular counts of theSarcopoterium spinosum seedlings were taken.

In June 1977, three samples of the top $8 \mathrm{~cm}$ soil were taken from the control and each fall burned plot. Soil samples were analysed for organic matter content and acidity.

In the laboratory living and dead plant material was separated by hand for both Sarcopoterium spinosum and herbaceous species, and it was weighed after oven-drying at $70^{\circ} \mathrm{C}$.

Yield data (live parts) were subjected to analysis of variance as a $2 \times 3$ factorial design. Moreover, frequency levels were compared to the control for each season with a one-way analysis of variance. When needed, the studentized range test was used (Hicks 1973). All tests were made at the 0.05 level of significance.

\section{Results}

\section{Cover and Species Composition}

Table 1 shows the most common species encountered in the plots. It appears that the fall-burned plots had relatively less Sarcopoterium spinosum and grass cover as well as litter than the spring-burned plots at the end of the 3-year burning period. On the contrary, forb cover and bare soil were most prevalent on the fall-burned plots. However, no particular species seemed to be favored by burning at any season.

Sarcopoterium spinosum was mostly affected by frequency of burning. At the end of the 3-year period, the cover of this species was reduced $40 \%, 80 \%$, and $90 \%$ in the once, twice, and thrice burned plots, respectively.

Other species were affected only slightly by frequency of burning. Dominant perennial grass Chrysopogon gryllus tended to decrease due to repeated burning, while another quite abundant perennial grass Hyparrhenia hirta tended to increase (Fig. 2).

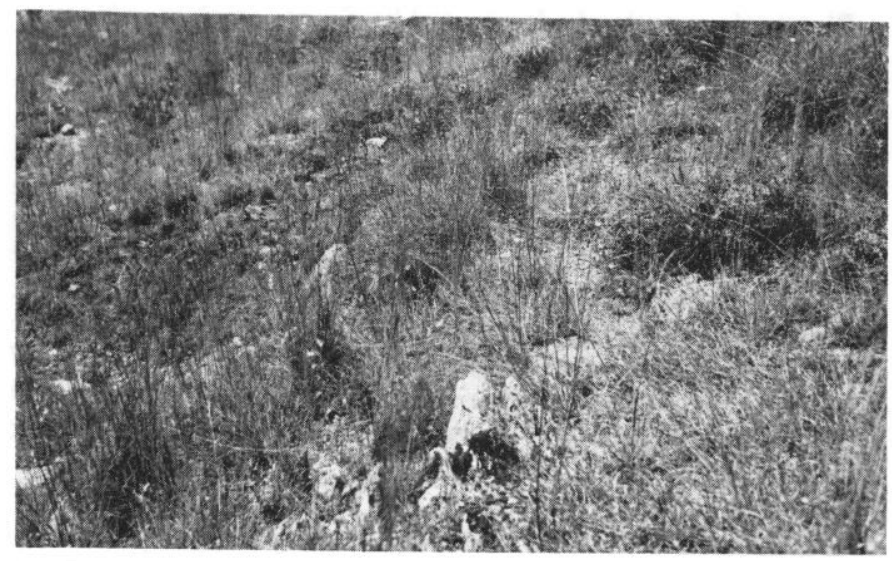

Fig. 2. View of the spring burned plot 4 months after the fire showing a severe reduction of the shrub and an increase of the grasses as compared to Figure 1.

Among the forbs, Pumana thymifolia appeared to be favored by repeated fires, while Thymus vulgaris was harmed. Annual legumes were more abundant in the plots burned repeatedly. Also, burning created more room for other forb species.

Finally, high burning frequency, at any season resulted in sharp increases of bare soil in the community while the amount of litter was at the same time decreased.

\section{Species reproduction}

Sarcopoterium spinosum recovered after burning by

Table 1. Vegetative cover $(\%)$ of the phryganic rangeland at the end of the 3-year burning period.

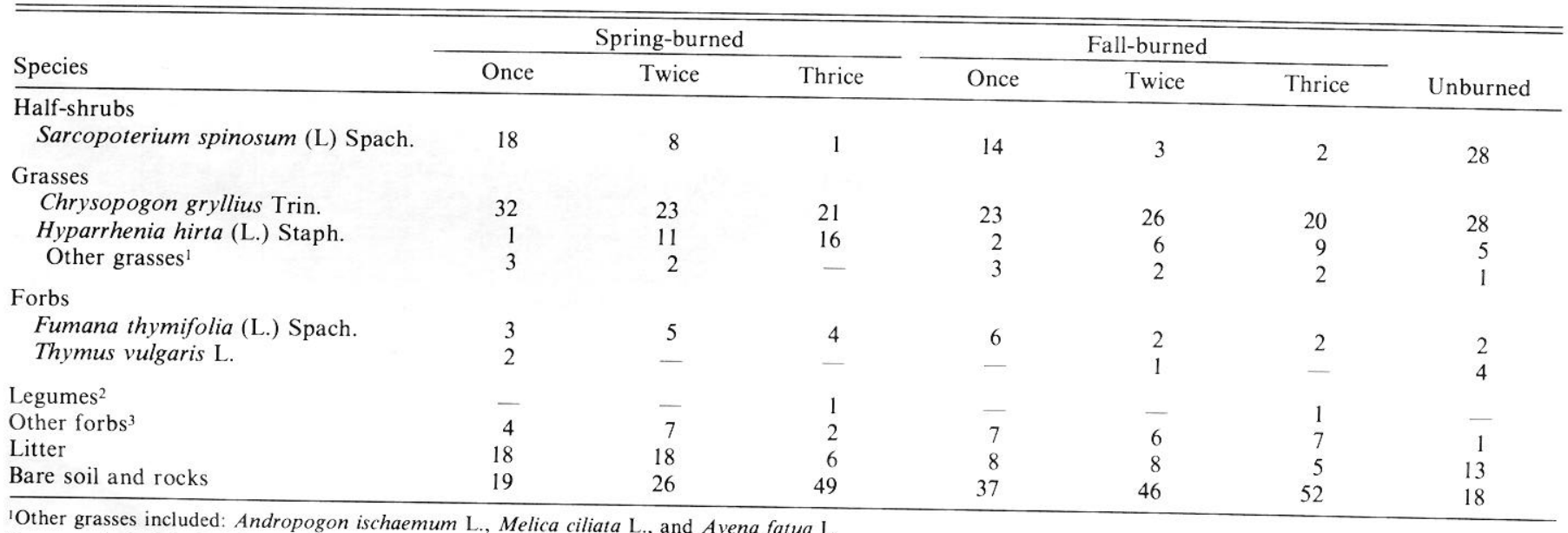

'Other grasses included: Andropogon ischaemum L., Melica ciliata L., and Avena fatua L.

${ }^{2}$ Legumes included: Trifolium campestre Schreb., T. arvense L., and T. angustifolium L.

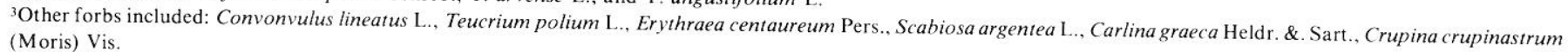


heavy sprouting. It was estimated that $95 \%$ of the burned plants sprouted from the root crown after each burn. Only the plants which were exposed to a very hot fire, as judged by the absence of any standing stem, died after burning.

Sprouts attained about one third of the original plant height at the end of the first growing season after burning. However, they produced seeds only in the second growing season since they were burned.

Although no single seedling was noticed in the unburned plots during the course of the experiment, a high population of such seedlings was established under the burned mother plants. I counted 1900 seedlings per square meter in early February under plants burned in the spring and fall of the year before. The population decreased $73 \%$ in late June of the same year. By June of the following year, the population had decreased $99 \%$. Only 8 seedlings remained in June of the third year. No seedlings were found away from the mother plants, where grass was growing, except in the bare spaces.

The surprising thing was that even spring burning resulted in seedling establishment. It was not clear whether the seeds germinated had come from the seed pool in the soil or from the plant crowns which retained some mature seeds from the previous growing season.

As far as the herbaceous species are concerned, the dominant perennials, either grasses or forbs, reproduced vegetatively after burning (Fig. 2).

\section{Yields}

Statistical analyses showed that season of burning did not have any significant effect on the yields (live plant parts) of both Sarcopoterium spinosum and herbaceous species. On the contrary, frequency of burning affected them significantly. Table 2 summarizes the yield results.

For Sarcopoterium spinosum specifically, the means of the twice and thrice burned plots did not differ significantly from each other but both reduced yields more than the onceburned plots. Moreover, all frequency levels of both seasons had significantly lower yields than the unburned plots.

Herbage yields, on the other hand, were affected less by frequency of burning. Only the thrice-burned plots of both seasons had significantly lower yicld compared to the control. The other two frequencies did not differ significantly from each other nor from the control.

The effect of burning frequency on the total yield was a combination of the effects on the two components already described (Table 2).

Table 2. Means of plant yields ( $\mathrm{kg} / \mathrm{ha}$ ) for the three burning frequencies over both (spring and fall) seasons and for the unburned plots at the end of the 3-year burning period.

\begin{tabular}{lcccc}
\hline \hline & \multicolumn{3}{c}{ Burned } \\
\cline { 2 - 4 } Species & Once & Twice & Thrice & Unburned \\
\hline $\begin{array}{l}\text { Sarcopoterium } \\
\begin{array}{l}\text { spinosum } \\
\text { Herbaceous vegetation }\end{array}\end{array}$ & 11 & $120^{\mathrm{a}}$ & $52^{\mathrm{a}}$ & $864^{\mathrm{b}}$ \\
Total & $1755^{\mathrm{c}}$ & 1074 & $529^{\mathrm{a}}$ & 1167 \\
\hline
\end{tabular}

Significantly (a) lower than other burned and unburned, (b) higher than burned, and (c) higher than other burned treat ments of the same species or groups of species at 0.05 level of significance.

A tendency for accumulation of litter (standing and lying dead) of both Sarcopoterium spinosum and herbaceous species was found in the less frequently burned and in the unburned plots. The percentages of dry weight of litter in the

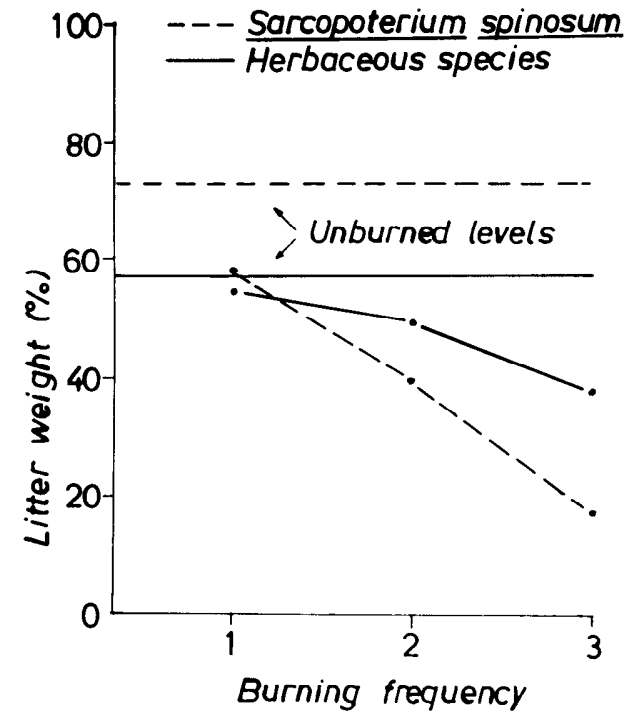

Fig. 3. Percentages of litter (standing and lying dead) in the biomass (live and dead) for the three burning frequencies over both (spring and fall) seasons as compared to the levels in the unburned plots.

biomass (live and dead) are graphed in Figure 3, which showed that the plots left unburned for three consecutive growing seasons tended to accumulate almost as much dead material as the unburned plots. This material consisted of dry twigs for the shrub and of dry leaves and stems for the herbs.

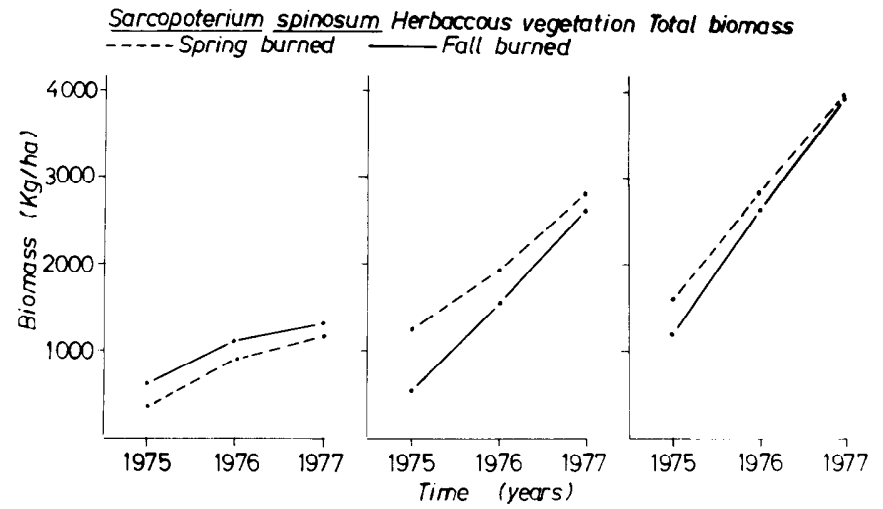

Fig. 4. Rate of biomass build up in the once-burned plots of the phryganic rangeland in 3 years after burning.

\section{Biomass Build-up after Burning}

For the once-burned plots in the spring and in the fall, the rate of biomass build up in 3 years is shown in Figure 4. It is apparent that the original differences between the two seasons tended to disappear towards the end of the 3-year period.

Sarcopoterium spinosum recovered faster when burned in the spring then in the fall. Regardless of the season, there was a rapid biomas build up from the first year to the second $(106 \%)$ and a slower one from the second to the third year $(22 \%)$.

By contrast, herbaceous vegetation recovered faster in the fall than in the spring. Over both seasons, there was a $92 \%$ increase in biomass from the first to the second and a $59 \%$ increase from the second to the third year.

Overall, total biomass built up faster when burned in the fall than in the spring. Averaging over both seasons, rates of 
biomass build up were $97 \%$ and $45 \%$ respectively from the first to the second and from the second to the third year. In actual data, $1,346.2 \mathrm{~kg} / \mathrm{ha}$ of biomass was added in the second year and $1,238.2 \mathrm{~kg} / \mathrm{ha}$, in the third. Since the biomass of the first year was $1,388.4 \mathrm{~kg} / \mathrm{ha}$, an average of $1,324.2 \mathrm{~kg} /$ ha was added from the one year to the next after burning.

\section{Effect on Soil}

Burning did not seem to have had any appreciable effect on soil based on the two soil properties measured, organic matter content and acidity. At the end of the 3-year burning period, the fall burned plots had $1.715 \%$ and 6.5 in the once burned, $1.409 \%$ and 6.2 in the twice and $1.965 \%$ and 6.5 in the thrice burned plots, respectively, for organic matter and $\mathrm{pH}$. The corresponding figures for the unburned plots were 1.712 and 6.3 .

Although not measured, no soil erosion in the burned plots was observed.

\section{Discussion and Conclusions}

The capacity of both Sarcopoterium spinosum and the herbaceous species to regenerate vigorously after burning may explain the lack of any significantly different effect between the two seasons on their yields.

However, the cover data indicated a tendency for both the shrub and the grasses to increase with spring burning at the expense of forbs, which in turn tended to increase with the fall burning. Taking into account that both dominant perennial grasses, Chrysopogon gryllus and Hyparrhenia hirta, are warm-season plants (Papanastasis, unpublished data), these results are reasonable, since spring burning normally favors the warm-season over the cool-season grasses (Wright 1974). On the other hand, fall burning usually favors forbs over grasses in natural grasslands (Daubenmire 1968). Moreoever, an increase of the herbaceous species (grasses and forbs) at the expense of the woody plants in the fall-burned plots as compared to the spring-burned ones was also found in a Quercus coccifera $\mathrm{L}$. garrique in southern France (Trabaud 1974).

Of the two components of vegetation, Sarcopoterium spinosum was affected more by frequent burning than herbaceous species. This explains why the shrub yields were significantly lower in the once- and twice-burned plots as compared to the control while the herbage yields were not reduced. Suppression of woody plants in favor of the herbaceous species by frequent fires has been found in other plant communities, too (Wright 1972, 1974; Trabaud 1977).

Shrubs usually regenerate after fire either vegetatively or by seeds (Wright 1972). However, several chaparral species possess both these capacities. An example is chamise (Adenostema fasciculatum), which produces both strumpsprouts and seedlings after burning (Biswell 1974). Sarcopoterium spinosum belongs to this latter group of species. In addition to sprouting, it regenerates readily by seeds, the germination capacity of which is enhanced by high temperatures (Papanastasis and Romanas 1977). Therefore, it can be considered as a highly adaptive species to recurring fires.

Its seedlings, though, are sensitive to competition from annual grasses (Litav and Orsham 1971). This is why no seedlings were observed in places covered by grasses in the community studied. It follows that burned phryganic rangelands deteriorate over time when overgrazed, because competition to Sarcopoterium spinosum seedlings from grasses is lessened and the shrub eventually gets denser.

Among the grasses, Hyparrhenia hirta seems to be favored by frequent burning, which suggests that it is well adapted to recurring fires. The same was also observed in Israel by Naveh (1974).

It is apparent that fire has only temporary effects on the phryganic rangelands. This can be illustrated by the relatively high speed that aerial biomass is built up after burning. Since the average rate of this build up was about $1,320 \mathrm{~kg} /$ ha per year in the once-burned plots, it follows that they will reach the unburned levels $(5,936 \mathrm{~kg} / \mathrm{ha})$ in about 4.5 years. Sarcopoterium spinosum, however, would need a longer time to build up its biomass to the original level, about 7.5 years. Herbaceous vegetation needs only 2.0 years for full recovery. More advanced communities require more time to recover after burning; for example, $Q$. coccifera gariques need 6 years (Trabaud 1977), while chaparral communities need about 20 to 25 years (Biswell 1974).

On the other hand, the phryganic ecosystem has a tendency to accumulate dead material and become decadent if unburned. About $2,200 \mathrm{~kg} /$ ha of such material was accumulated in the once-burned plots in a 3-year period, whereas the unburned plots had about $3,900 \mathrm{~kg} / \mathrm{ha}$. Meanwhile, Wright (1974) states that build up of litter in excess of $2,240 \mathrm{~kg}$ / ha may have adverse effects on nutrient cycling in stagnated grassland communities and he suggests the use of fire to stimulate forage production.

Hence, it appears that phryganic communities are rejuvenated by frequent fires. However, if burning is too frequent, Sarcopoterium spinosum is significantly supressed but herbage production is decreased; if too infrequent, the shrub grows up, large amounts of the production goes to the detritus form and the herbage produced becomes rather unavailable. Therefore, the optimum fire frequency should lie between these two extremes.

The results of this study suggest that prescribed burning every 3 to 4 years, preferably in early fall, should be applied for rational fire management of the phryganic rangelands. Such burning will keep Sarcopoterium spinosum reasonably suppressed while securing at the same time a high availability of the herbage produced. However, further research is needed to verify these findings over the entire phrygana zone and under actual grazing conditions.

\section{Literature Cited}

Biswell, H.H. 1974. Effects of fire on chaparral. p. 321-360. In: T.T. Kozlowski and C.E. Ahlgren (Eds) Fire and Ecosystems. Academic Press Inc. N.Y.

Daubenmire, R. 1968. Ecology of fire in grasslands. In: Adv. in Ecol. Res. 5: 209-266.

Debazac, E.P. and G. Mavrommatis. 1969. Note sur les formations forestières "à feuilles persistantes" en Grèce. Inst. Rech. Forest., Athènes. $23 \mathrm{p}$.

Hicks, C.R. 1973. Fundamental Concepts in the Design of Experiments. 2nd Ed. Holt, Rinehart and Winston Inc., N.Y. 349 p.

Joint Committee. 1962. Basic Problems and Techniques in Range Research. National Academy of Sciences, Nat. Res. Council Pub. 890. $341 \mathrm{p}$.

Litav, M., and G. Orshan. 1971. Biological Flora of Israel. 1. Sarcopoterium spinosum (L.) SP. Israel J. Bot. 20: 48-64.

Mueggler, W.F. 1976. Ecological role of fire in western woodland and range ecosystems. p. 1-9. In: Use of Prescribed Burning in Western Woodland and Range Ecosystems, a Symposium. Utah State Univ., Logan. 
Munz, P.A., and D.D. Keck. 1968. A California Flora. University Calif. Press. $1,681 \mathrm{p}$.

Naveh, Z. 1974. Effects of fire in the Mediterranean region. p. 401-434. In: T.T. Kozlowski and C.E. Ahlgren (Eds) Fire and Ecosystems. Academic Press Inc., N.Y.

Papanastasis, V.P. 1977. Fire ecology and management of phrygana communities in Greece. p. 476-482. In: H.A. Mooney and C.E. Conrad (Techn. Coords), Proc. Symp. on Environmental Consequences of Fire and Fuel Manage. in the Med. Ecosystems. U.S. Dep. Agr. Forest Serv. General Tech. Rep. WO-3.

Papanastasis, V.P., and L.C. Romanas. 1977. Effect of high temperatures on seed germination of certain Mediterranean half-shrubs. Forest Res. Inst., Bull. 86.30 p. (In Greek with English summary).
Trabaud, L. 1974. Experimental study on the effects of prescribed burning on a Quercus coccifera L. garrique. Early results. Proc. 13th Ann. Tall Timbers Fire Ecology Conf., 97-129.

Trabaud, L. 1977. Comparison between the effect of prescribed fires and wildfires on the global quantitative evolution of the kermes scrub oak (Quercus coccifera L.) garriques. p. 271-282. In: H.A. Mooney and C.E. Conrad (Techn. Coords.), Proc. Symp. on Environmental Consequences of Fire and Fuel Manage. in the Med. ecosystems. U.S. Dep. Agr. Forest Serv. General Tech. Rep. WO-3.

Wright, H.A. 1972. Shrub response to fire. p. 204-217. In: C.M. McKell et al. (eds) Wildland Shrubs-Their Biology and Utilization. U.S. Dep. Agr. Forest Serv., General Tech. Rep. INT-1.

Wright, H.A. 1974. Range burning. J. Range Manage. 27: 5-11.

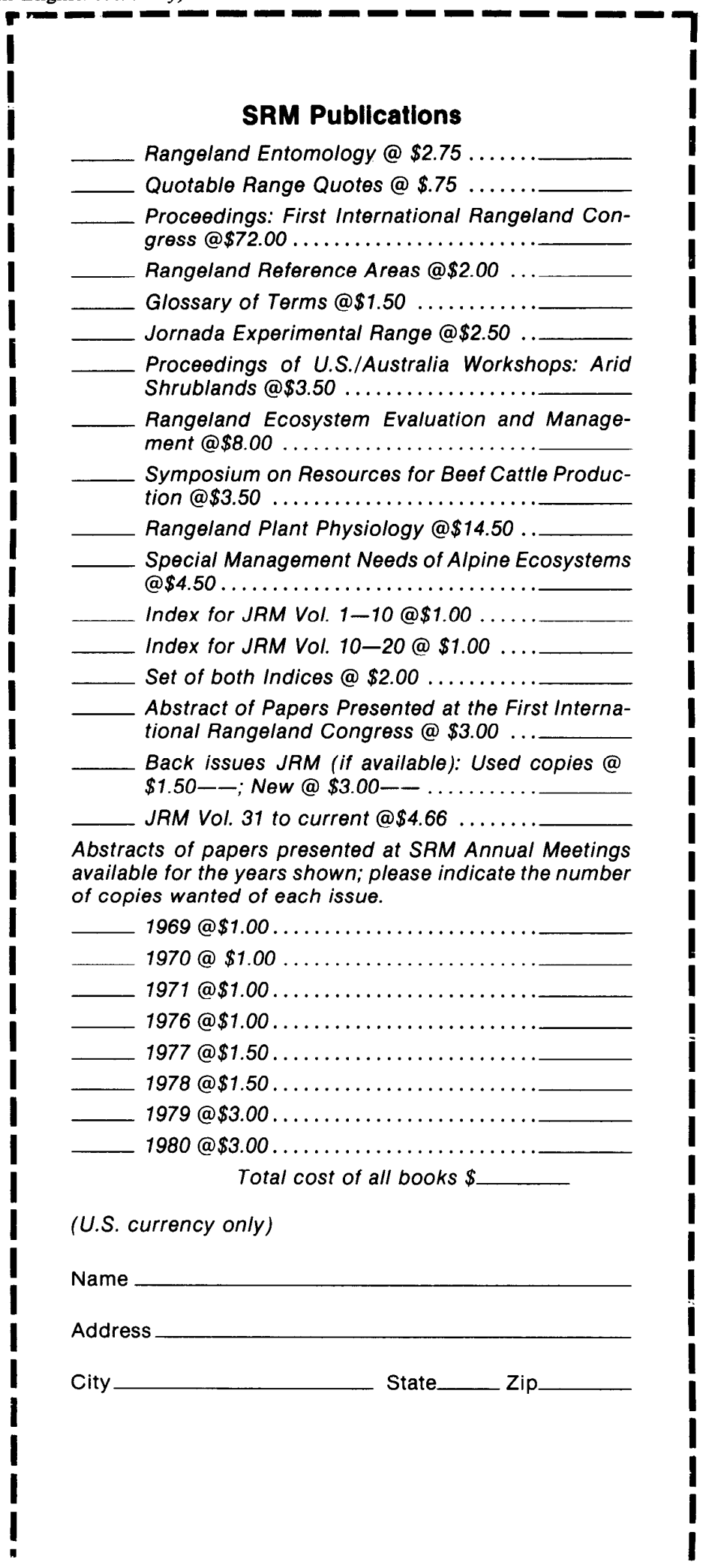

